\title{
THE ROLE AND LIABILITY OF CERTIFICATION ORganisations IN Transnational Value Chains
}

\section{CAROLA GLINSKI*}

\section{Peter RotT**}

Certification organisations have become important players in the monitoring of compliance with social and environmental standards. This is particularly the case in relation to corporate operators producing in or sourcing from developing countries. At the same time, some of the worst industrial disasters in recent years, such as the Ali Enterprises factory fire in Pakistan or the collapse of the Rana Plaza building in Bangladesh, occurred after the relevant operators had been certified for their compliance with standards. This raised doubts about the care that the relevant certification organisation had exercised. This article explores potential grounds on which corporate social responsibility (CSR) certification organisations may incur liability towards third parties, in particular employees of subsidiaries or suppliers. To this end, it discusses the functions of certification generally before it analyses the potential liability of certification bodies under German and English law. It considers various circumstances under which certification takes place, including certification that is required by law, certification that is required to obtain certain benefits, such as tax reductions, certification within private CSR schemes and the entirely voluntary use of CSR certification as an instrument of supply chain control.

\section{INTRODUCTION}

As a result of the corporate social responsibility (CSR) debate, and with the increasing risk of parent companies having to assume liability for the operations of their subsidiaries or even suppliers, the corporate governance of such

\footnotetext{
* Senior Researcher, Centre for Private Regulation (CEVIA) at the University of Copenhagen, Denmark.

** Professor of Civil Law, European Private Law and Consumer Law at the University of Kassel, Germany.
} 
structures and the monitoring of supplier compliance with certain standards have become crucial. That task is often outsourced to specialised organisations that certify the subsidiaries' or suppliers' satisfaction of certain standards or requirements. For example, in the well-known case of the factory fire of Ali Enterprises in Pakistan, with 260 killed and 32 injured, the Italian certification organisation RINA was involved in the monitoring of, amongst other things, the fire safety of the factory. In the case of the collapse of the Rana Plaza building in Bangladesh, the German certification organisation TÜV Rheinland and the French certification organisation Bureau Veritas (or rather their subsidiaries) had issued social audits. ${ }^{1}$

Whilst practical and theoretical concerns relating to the quality, in particular, of solicited certification paid for by the monitored business have been discussed in academic writing - for example in the context of solicited credit rating ${ }^{2}-$ the potential liability of certification organisations towards third parties, and in particular victims of malpractice, has received little attention in the past. This has changed with the spectacular breast implant scandal involving the French company PIP, in the course of which TÜV Rheinland became the target of tort law claims of victims. In that case, however, specific issues of EU medical devices law were at the centre of the debate. Still, given the steep rise of the certification industry in the recent past, and the particular importance of CSR certification, the liability of certification organisations deserves broader discussion. $^{3}$

This article therefore explores potential grounds on which CSR certification organisations may incur liability towards third parties, taking into account the specific functions that certification has in transnational value chains.

The article starts with some consideration of the function of certification as a form of privatisation of state control, or as a substitute for state control. It then presents the potential legal grounds under German and English law for the liability of certification bodies towards victims of health and safety problems that the certification body should have discovered and reported. English law is chosen as representative of the common law world because under the rules of

\footnotetext{
${ }^{1}$ See Carolijn Terwindt and Miriam Saage-Maaß, Zur Haftung von Sozialauditor_innen in der Textilindustrie, August 2017, in particular 13 and $15<\mathrm{http} / / /$ library.fes.de/pdffiles/iez/13588.pdf $>$; Carolin Terwindt, Sheldon Leader, Anil Yilmaz-Vastardis and Jane Wright, 'Supply Chain Liability: Pushing the Boundaries of the Common Law?' (2017) 8(3) Journal of European Tort Law 261, 274.

${ }^{2}$ See, eg, Axel Halfmeier, Die Haftung von Ratingagenturen gegenüber Kapitalanlegern: Von Sydney lernen? (2014) Verbraucher und Recht [VuR] 327, 330-2.

${ }^{3}$ See also Peter Rott (ed), Certification - Trust, Accountability, Liability (Springer, 2019) (forthcoming).
} 
private international law, at least under article 4(1) of Regulation (EU) No $864 / 2007$ on the law applicable to non-contractual obligations (Rome II)), ${ }^{4}$ it is the law of the country where the damage occurs that applies to the potential claims of victims; and those countries where the most spectacular disasters until now have occurred were countries whose laws are based on English law, due to their colonial history, including Pakistan, Bangladesh and Nigeria. German law represents a typical continental legal system, and it offers rich case law concerning various types of certification.

The article discusses in detail different reasons why, and situations in which, certification bodies are involved in the governance structure in question. One crucial factor to be considered is the extent to which there is public law in the background of certification. Therefore, the article first discusses the situation where certification is mandated by public law before it moves step by step towards the voluntary involvement of certification bodies. After a few words on the practically important issue of causation, the article closes with a summary of the findings.

\section{Safety Certification as Privatisation of a PUBLIC TASK OR A GAP-FILLER}

Within a nation state, public security is a classic public task: the 'state duty to protect' its citizens, as enshrined in national constitutions ${ }^{5}$ as well as in EU law ${ }^{6}$ and in international treaties. ${ }^{7}$ This encompasses the regulation and control of health and safety issues, accompanied by state liability in case control has not been carried out with due care. In various fields, however, the control of adherence to the safety requirements of certain, inherently high-risk, activities or technologies has been privatised and outsourced to private certification bodies. These certification bodies remove from the state the burden of performing the relevant duties through public authorities. ${ }^{8}$

\footnotetext{
${ }^{4}$ [2007] OJ L 199/4.

${ }^{5}$ In Germany, that duty is derived from the right of life and physical integrity as enshrined in article 2 paragraph 2 of the Basic Law (Grundgesetz; GG). See Georg Hermes, Das Grundrecht auf Schutz von Leben und Gesundheit (C F Müller, 1987).

${ }^{6}$ For article 2 (right to life) and article 3 (right to the integrity of the person) of the Charter of Fundamental Rights of the European Union, see Hans D Jarass, Charta der Grundrechte der Europäischen Union (C H Beck, $3^{\text {rd }}$ ed, 2016), art 2 para 8 and art 3 para 10.

${ }^{7}$ For the right to life under article 2 of the European Convention on Human Rights, see, for example, European Court of Human Rights, 24 March 2011 — Giuliani and Gaggio v Italy.

${ }^{8}$ See also Bundesgerichtshof [German Federal Court of Justice], III ZR 261/54, 30 September 1957, reported in [1957] Neue Juristische Wochenschrift (NJW) 1927, 1928.
} 
In order to guarantee the proper execution of control by private bodies, the state usually needs to accredit those bodies on the basis of their capabilities. The bodies would need, for example, to demonstrate sufficient expertise, means, independence and impartiality. Thus, the 'state duty to protect' is replaced by the 'state duty to ensure protection'. ${ }^{9}$ Still, liability for damage caused by a failure to fulfil control duties is an important cornerstone of the safety architecture. Consequently, courts have held that, for the assignment of liability, it is not relevant whether it is a public or a private entity that carries out control tasks; what matters instead are the type and relevance of the duties. These duties are defined by law, and they are part of a legal structure that is meant to guarantee safety. ${ }^{10}$

Following the transnationalisation of production and risks, not only control tasks but also the health and safety standards to be met are increasingly being privatised. Thus, CSR certification in transnational production chains is usually a purely private exercise: In many cases, producers voluntarily join a private standardisation system and obtain certification by accredited certifiers; or - in a way that is even less formalised - engage a certification body to certify their compliance with an agreed bundle of CSR requirements. The issue at stake, however, remains the same: the control of adherence to certain health and safety requirements in order to ensure public safety or the safety of concerned third parties.

In economic terms, legal liability for insufficient control and for certification without the relevant requirements being met, is an important mechanism to avoid dysfunctional incentives resulting from the relationship between certifier and certified entity. This triggers the question whether, and to what extent, private law, and in particular private liability, can function as a substitute for state-driven health and safety systems in purely private certification systems. This article distinguishes three ideal types of certification situations when analysing the potential liability of certification bodies: the mandatory certification of mandatory legal requirements; the mandatory certification of voluntary (legal or private) requirements; and purely voluntary certification.

\footnotetext{
9 See also Sebastian Unger, 'Herstellerbegleitung oder Marktüberwachung? Zur Haftung "benannter Stellen" im Medizinproduktrecht' [2017] Europäische Zeitschrift für Wirtschaftsrecht (EuZW) 299, 300-2.

${ }^{10}$ Ibid.
} 


\section{POTENTIAL GROUNDS OF LIABILITY}

The general problem with the liability of certification bodies is that they do not stand in a contractual relationship with the potential victim of negligent certification such as, for example, the employees in a factory that collapses or burns down. Thus, liability can only be found outside the field of contract law (in a narrow sense; for a broad understanding see below, III A 2). German law and English law appear to differ considerably in their doctrinal approaches to third party liability, although this article will show that, while the concepts differ, the results may be quite similar.

\section{A German Law \\ 1 Tort Law}

The natural starting point for third-party liability is tort law. Here, German law avails itself of, besides a number of special statutory torts, two main provisions for tortious liability.

Under § 823 paragraph 1 of the German Civil Code (Bürgerliches Gesetzbuch; BGB), a person who, intentionally or negligently, unlawfully injures the life, body, health, freedom, property or another right of another person is liable to make compensation to the other party for the damage arising from this. This paragraph can be loosely compared to the tort of negligence in English law. In the case of an omission or of bad performance, liability requires a duty to act in favour of the potential victims, which normally results from a risky activity or from control over a source of risk. As certification bodies do not themselves create risks for workers in or neighbours of production sites, the challenge is to derive a duty of care from their function to assess risks and to monitor production sites.

The BGB at $\S 823$ paragraph 2 imposes liability on a person who has breached a law that is 'meant to protect the victim' (Schutzgesetz), thereby causing harm to the victim. In the context of certification, this provision requires a legal provision relating to the duties of a certification body, and it is strictly dependent on the breach of that legal provision. In other words, once a certification body complies with the legal provision, it cannot be liable under $\S$ 823 paragraph 2 BGB.

A special provision, $\S 839 \mathrm{BGB}$, deals with torts committed by civil servants, to which we return below. 


\section{$2 \quad$ Contract with Protective Effect on Third Parties}

Third party liability can also arise out of a contract (in this case between the producer and a certification body) with protective effects on third parties (for example, the employees). The concept of a "contract with protective effect for third parties' was developed by German courts and doctrine in order to cope with perceived deficiencies in German tort law. ${ }^{11}$ Its main field of application is liability for pure economic loss (where German tort law is particularly restrictive), but it can also apply to physical damage.

Importantly, and peculiarly, the protective effect does not need to be agreed upon by the parties. According to the jurisprudence of the Bundesgerichtshof (BGH) [German Federal Court of Justice], it is rather the result of an objective, normative, complementary interpretation of the actual agreement in the light of the principle of good faith. ${ }^{12}$ What is decisive are the typical social interests stemming from the main contract, its purpose, the legitimate expectations of third parties, and principles of equity and usefulness. Thus, the protection of third parties may be included in the purpose of a contract even where this is clearly not in the interest of one of the parties, namely the party who would be liable (in this case the certification organisation), if the will of the party or parties is contrary to good faith. ${ }^{13}$ For that reason, the contract with protective effect for third parties is, in substance, closer to tort law than to contract law. This is why, in private international law, the potential liability towards third parties is considered, in academic writing, to come under international tort law. ${ }^{14}$

The courts have developed typical cases of contracts that they ascribe a protective effect on third parties to. One group is concerned with the liability of experts in whose expertise the third party trusts. One leading case turned on the liability of an architect who was commissioned to provide an expert opinion

${ }^{11}$ On this development in Germany, see Mauro Bussani and Vernon Palmer, 'The Liability Regimes of Europe - Their Facades and Interiors' in Mauro Bussani and Vernon Palmer (eds), Pure Economic Loss in Europe (Cambridge University Press, 2003) 120, 150-1.

${ }^{12}$ See Bundesgerichtshof [German Federal Court of Justice], IX ZR 145/11, 14 June 2012, reported in [2012] NJW 3165, 3167.

${ }^{13}$ See explicitly Bundesgerichtshof [German Federal Court of Justice], X ZR 250/02, 20 April 2004 reported in [2004] NJW 3035, 3036. See also Peter Gottwald's commentary in Franz Jürgen Säcker et al (eds), Münchener Kommentar zum Bürgerlichen Gesetzbuch (C H Beck, 7th ed, 2016) vol 2 § 328 BGB paras 168-9.

${ }^{14}$ For details, see Anatol Dutta, 'Das Statut der Haftung aus Vertrag mit Schutzwirkung für Dritte' [2009] Praxis des Internationalen Privat- und Verfahrensrechts (IPRax) 293. See, however, OLG Frankfurt [Frankfurt Higher Regional Court], 4 U 269/16, 21 March 2018, reported in [2018] Beck-Rechtsprechung (BeckRS) 9098, applying international contract law without further explanation. 
on the condition of a house. The opinion was then presented to potential buyers, with the architect's knowledge. The expert opinion was flawed since the architect had never inspected the roof which was defective. The buyer sued the architect (because the seller was bankrupt) and won the case in court. ${ }^{15}$ This type of expert liability is also discussed, for example, in relation to rating agencies, ${ }^{16}$ and it has been applied to a classification society that certified the classification of a particular vessel. ${ }^{17}$

Trust by the third party is, however, not a necessary ingredient of a contract with protective effect on third parties. Other court decisions address situations where the third party is the 'real' beneficiary of the contractual duty, or where the third party comes into contact with the contractual duty due to a private or work relationship with the other party. ${ }^{18}$ This latter would be the relevant case group for situations in which certification organisations act on behalf of the employer or its parent company or the buyer in a supply chain. This is particularly true where the contracting party is responsible for the well-being of the third party, ${ }^{19}$ although this is not an indispensable precondition of a contract with protective effects on third parties. ${ }^{20}$

\section{B English Law}

In English tort law, the liability of certification bodies may stem from the tort of negligence. Very generally, liability for negligence arises when one person breaches a duty of care owed to another who suffers damage resulting from that breach. Under the general rules of the tort of negligence, the crucial question would be whether, by entering into a certification contract, the certification body assumes a duty of care, for example, for the workers at the factory that it certifies.

\footnotetext{
${ }^{15}$ Bundesgerichtshof [German Federal Court of Justice], III ZR 50/94, 10 November 1994, reported in [1995] NJW 392.

${ }^{16}$ For details, see Halfmeier, above n 2. Until now, the courts have been reluctant to establish liability for negligent ratings, pointing at the potentially unlimited and therefore unforeseeable number of claimants; see, eg, Landgericht Düsseldorf [Düsseldorf Regional Court], $10 \mathrm{O}$ 181/15, 17 March 2017, reported in [2017] VuR 383, 384. For convincing counter-arguments, see Halfmeier, above $\mathrm{n} 2$.

${ }^{17}$ See Oberlandesgericht Hamburg [Hamburg Higher Regional Court], 6 U 34/90, 14 June 1990, reported in [1991] Versicherungsrecht (VersR), 476.

${ }^{18}$ See Gottwald, above n 13, § 328 BGB para 170.

${ }^{19}$ See Bundesgerichtshof [German Federal Court of Justice], IVa ZR 20/82, 2 November 1983, reported in [1984] NJW 355.

${ }^{20}$ See Bundesgerichtshof [German Federal Court of Justice], IX ZR 145/11, 14 June 2012, reported in [2012] NJW 3165, 3167.
} 
The classic test for this is the three stage test set out in Caparo v Dickman, according to which the claimant has to establish that a) the harm was foreseeable; b) the relationship between the claimant and the defendant was sufficiently proximate; and c) it is fair, just and reasonable that the law should impose a duty of a given scope on one party for the benefit of the other. ${ }^{21}$

An assumption of responsibility is one way to establish the proximity that is necessary for liability under the tort of negligence. ${ }^{22}$ It should, however, be noted that the Caparo v Dickman test and the assumption of responsibility tests are not different tests but that they are only emanations of the same basic idea, namely, that it must be fair and reasonable to impose liability on the defendant. ${ }^{23}$

The voluntary assumption of a duty of care is not alien to English tort law. ${ }^{24}$ Authors have described the assumption of responsibility as a gap-filler between tortious and contractual liability, ${ }^{25}$ showing its relation with the German doctrine of contracts with protective effect on third parties. It is just that English law chose tort law as the relevant category for this type of responsibility.

Assumption of responsibility covers situations where third parties rely on expert opinions, as first established in the landmark case of Hedley Byrne $v$ Heller. ${ }^{26}$ Crucially, English courts regard assumed responsibility as a responsibility that has been voluntarily accepted by the expert in question. ${ }^{27} \mathrm{As}$ in the case of the German law on contracts with protective effect on third parties, however, 'voluntary' does not necessarily mean that the parties actually wish the one party to be liable for damage caused to third parties. Case law suggests that it is rather an objective test. ${ }^{28}$ For example in Chandler v Cape Lady Justice Arden, while applying the concept of assumption of responsibility,

${ }^{21}$ [1990] UKHL 2.

${ }^{22}$ See, eg, Bishara $v$ Sheffield Teaching Hospitals [2007] EWCA, Civ 353 [11].

${ }^{23}$ See, eg, Lungowe and others $v$ Vedanta Resources Plc and Konkola Copper Mines Plc [2017] EWCA Civ 1528 [81].

${ }^{24}$ Stathis Banakas, 'Voluntary Assumption of Tort Liability in English Law: A Paradox?' [2009] (4) InDret 1; Andrew Robertson and Julia Wang, 'The Assumption of Responsibility' in Kit Barker, Ross Grantham and Warren Swain (eds), The Law of Misstatements: 50 Years on from Hedley Byrne v Heller (Hart Publishing, 2015) 49.

${ }^{25}$ See Martin Petrin, 'Assumption of Responsibility in Corporate Groups: Chandler v Cape plc' (2013) 76 Modern Law Review 603, 614 with fn 74.

${ }^{26}$ [1964] AC 465.

${ }^{27}$ See Henderson v Merrett Syndicates Ltd [1994] 3 All ER 506, 528-9.

${ }^{28}$ See Williams and another v Natural Life Health Foods Ltd and Mistlin [1997] 1 BCLC 131 (Lord Steyn). 
concluded that 'this case demonstrates that in appropriate circumstances the law may impose on a parent company responsibility for the health and safety of its subsidiary's employees'. ${ }^{29}$ This position has, however, been disputed in academic writing. ${ }^{30}$

Moreover, English courts have applied the doctrine of assumption of responsibility to physical harm caused to third parties. According to the traditional formula, a sufficient relationship of proximity will exist when someone possessed of a special skill undertakes to apply that skill for the assistance of another person who relies upon such skill and there is a direct and substantial reliance by the plaintiff on the defendant's skill. ${ }^{31}$ In Phelps $v$ Hillingdon London Borough Council, the House of Lords held that a person exercising a particular skill or profession might owe a duty of care in its performance to those who might foreseeably be injured if due care and skill were not exercised. ${ }^{32}$

The courts have applied the concept of assumption of responsibility in many ways, for which they have sometimes been criticised in academic writing. ${ }^{33}$ As Lord Bingham emphasised in Customs and Excise Commissioners v Barclays Bank plc, ${ }^{34}$ much depends on 'the detailed circumstances of the particular case and the particular relationship between the parties in the context of their legal and factual situation as a whole'. Whether there has been an assumption of responsibility is a mixed question of fact and law but the importance of the detailed circumstances means that the findings of the tribunal of fact as to those circumstances are likely to be of considerable significance. ${ }^{35}$

\section{LIABILITY OF CERTIFICATION BOdIES}

In this section, we apply the potential grounds of liability as briefly set out above to the various situations in which certification takes place. We start with situations in which safety certification is mandated by law. We then turn to a situation where certification is voluntary but constitutes a precondition for state benefits. Moving on to the private sphere, we consider the situation where certification takes place in the framework of a private scheme with or without

\footnotetext{
${ }^{29}$ Chandler v Cape plc [2012] EWCA Civ 525 [80] (emphasis added).

${ }^{30}$ For an account, see Robertson and Wang, above $\mathrm{n} 24$.

${ }^{31}$ See Capital \& Counties PLC v Hampshire County Council [1997] QB 1004 [1034].

${ }^{32}$ Phelps $v$ Hillingdon London Borough Council [2000] 4 All ER 504.

${ }^{33}$ On which see Petrin, above n 25, 611-8.

34 [2007] AC 181.

${ }^{35}$ See Lejonvarn v Burgess [2017] EWCA Civ 254 [69].
} 
the involvement of representatives of the interests of potential victims, such as NGOs or trade unions that are active in setting CSR standards. The final situation that we consider is the entirely voluntary use of third party certification within a company's health and safety management system.

\section{A Legally Required Certification}

\section{The National Context}

a) German Road Traffic Safety Certification Safety certification as a public law task has existed for a long time. One of the most prominent activities of private organisations - such as the various TÜVs but nowadays also competitors such as DEKRA (the Deutscher KraftfahrzeugÜberwachungs-Verein or German Motor Vehicle Inspection Association) - is the regular bi-annual control of the safety of cars, under $\S 29$ of the German Road Vehicle Registration Regulation (Straßenverkehrszulassungsordnung, $\mathrm{StVZO}$ ). The private organisations that perform the controls are entrusted with this task by state authorities. The experts carrying out the controls must have a specific education that is regulated by law, and they must be accredited. ${ }^{36}$ In the past, not all safety controls met the relevant standards, and there have been cases in which, for example, the inadequate safety of cars that had just been checked led to accidents.

In German jurisprudence, the question concerning liability was answered as follows. Without any doubt, the purpose of $\S 29 \mathrm{StVZO}$ is to keep unsafe cars away from public roads. ${ }^{37}$ Thus, the experts who perform the controls owe a duty of care to the victims of unsafe cars that should have been removed from public roads.

More controversial was the issue of whether liability lies with the certifier or with the state. In the German legal system, article $34 \mathrm{GG}$ and $\S 839$ of the Civil Code (Bürgerliches Gesetzbuch, BGB) deal with state liability. Under article $34 \mathrm{GG}$, if any person, in the exercise of a public office entrusted to him, violates his official duty to a third party, liability shall rest principally with the state or public body that employs him. The reason is that the victim should be able to

\footnotetext{
${ }^{36}$ See the Gesetz über amtlich anerkannte Sachverständige und amtlich anerkannte Prüfer für den Kraftfahrzeugverkehr [Act on officially recognised experts and officially recognised inspectors for road traffic] (KfSachvG) of 22 December 1971, Bundesgesetzblatt (BGBl) 1971 I, 2086.

37 See Bundesgerichtshof [German Federal Court of Justice], III ZR 178/53, 11 July 1955, reported in [1955] NJW 1316.
} 
claim damages from a solvent defendant. ${ }^{38}$ Thus, if the certification organisation exercises a public office and thereby causes damage accidentally, it is not the certification organisation but the state - in this case the relevant Land - that is liable. ${ }^{39}$

Indeed, the civil courts have treated the activities under $\S 21 \mathrm{StVZG}$ as the exercise of a public office. In the leading judgment of November 1967, the Federal Supreme Court (BGH) emphasised that it did not matter that the TÜV was a private entity. What matters instead is the type and the relevance of the duties of the TÜV experts. These are defined by law, and they are part of a legal structure that is meant to guarantee the safety of road traffic, thus to perform a public duty. ${ }^{40}$ Although the private organisations, such as the various TÜVs, or DEKRA, or their experts, could not themselves issue binding decisions relating to the admission of cars to public traffic, their report is the relevant basis for the decision of the competent authority. The BGH also decided that the fact that the TÜV experts are neither commissioned nor paid by the state ${ }^{41}$ but by the car owner was irrelevant, since, after all, the car owner had to pay for a service that was organised by the state in the interest of the car owner. ${ }^{42}$

b) English Aircraft Certification Certification as a public law requirement has been dealt with in the case of Perrett $v$ Collins,${ }^{43}$ dealing with an aircraft crash.

The flying of aircraft in the United Kingdom is regulated by the Civil Aviation Act 1982 (CAA 1982). Section 60 authorises the Crown by Order in Council to give effect to the obligations of the United Kingdom under the Chicago

\footnotetext{
${ }^{38}$ See Landgericht Berlin [Berlin Regional Court], 53 S 229/66, 28 April 1967, reported in [1967] NJW 1663, 1664.

${ }^{39}$ For similar questions relating to vessel classification, see Vibe Ulfbeck and Anders Møllmann, 'Public Function Liability of Classification Societies' in Rott, above n 3 (forthcoming).

${ }^{40}$ See Bundesgerichtshof [German Federal Court of Justice], VII ZR 34/65, 30 November 1967, reported in [1968] NJW 443. See also Landgericht Berlin [Berlin Regional Court], 53 S 229/66, 28 April 1967, reported in [1967] NJW 1663.

41 Unlike an expert in construction analysis in an earlier state liability case (see Bundesgerichtshof [German Federal Court of Justice], III ZR 48/62, 27 May 1963, reported in [1963] NJW 1821), and a doctor who was commissioned by the competent Land to examine harm caused by war injuries (see Bundesgerichtshof [German Federal Court of Justice], III ZR 194/59, 19 December 1960, reported in [1961] NJW 969).

${ }^{42}$ See Bundesgerichtshof [German Federal Court of Justice], VII ZR 34/65, 30 November 1967, reported in [1968] NJW 443.

${ }^{43}$ [1998] EWCA Civ 884.
} 
Convention ${ }^{44}$ and to regulate air navigation. The Civil Aviation Authority is the statutory regulator of air transport in the United Kingdom. Section 3 of the 1982 Act lays down the functions of the Authority which include

such functions as are for the time being conferred on it by or under Air Navigation Orders with respect to the registration of aircraft, the safety of air navigation and aircraft (including airworthiness), the control of air traffic, the certification of operators of aircraft ...

The relevant Air Navigation Order for the purposes of this case was the Air Navigation Order 1989. Under article 7(1) of the Order there is a requirement that an aircraft should not fly unless a valid Certificate of Airworthiness is in force in relation to the aircraft. Article 8(1) of the Order provides that the Authority shall issue a certificate of airworthiness if it is satisfied that the aircraft is fit for flying having regard to the design, construction, workmanship and materials of the aircraft which it considers necessary for the airworthiness of the aircraft.

Under article 110 CAA 1982, the Civil Aviation Authority may approve a person as qualified to furnish reports to it and may accept such reports. In Perrett $v$ Collins, ${ }^{45}$ it was a safety inspector who negligently issued the certificate despite the fact that the aircraft was unsafe. The Court of Appeal found that inspector liable because of his function within a system of controls that is meant to protect the passengers and the public from crashes of unsafe aircraft.

Interestingly, and in line with German case law, the court distinguished this from situations where only economic interests are harmed and saw these as outside the scope of protection of the CAA $1982 .{ }^{46}$

A difference from the German legal system lies in the possibility in the UK of suing the person immediately in charge of the safety relevant duty, which is not possible under German state liability law. ${ }^{47}$ Under the English system of the CAA 1982, the person in charge will, however, be indemnified by the regulatory authority, the Civil Aviation Authority.

\footnotetext{
${ }^{44}$ Convention on International Civil Aviation, signed 7 December 1944 (entered into force 4 April 1947) <https://www.icao.int/publications/pages/doc7300.aspx>.

${ }^{45}$ [1998] EWCA Civ 884.

${ }^{46}$ See also Philcox v Civil Aviation Authority (Unreported, Court of Appeal, Civil Division, Staughton LJ, Millett LJ and Ward LJ, 25 May 1995).

${ }^{47}$ See also Ulfbeck and Møllmann, above $n 39$.
} 


\section{The European Context - EU Product Safety Law}

The European context is somewhat special, as here we face a two-fold question. First, does EU law itself impose, or does it rather require Member States to impose, liability on certification bodies that breach their duties? Alternatively, do Member States impose liability autonomously?

Safety certification is also an essential component of EU product safety law, ${ }^{48}$ and the role and liability of certification organisations in EU product safety law have received wide attention in the context of the PIP breast implant scandal. The system can be briefly illustrated with the example of EU medical devices law.

Medical devices come under a self-certification system, first established by Directive 93/42/EEC concerning medical devices. ${ }^{49}$ It was replaced in 2017 by the Medical Devices Regulation (EU) 2017/745..$^{50}$ This system requires the producer who puts a medical device into circulation to certify that the device complies with the required safety standards. The EU legislator has, however, recognised that some medical devices pose a higher risk to patients than others. For example, whilst the risk associated with a hypodermic needle appears to be low, the same does not apply to artificial hips or breast implants. Therefore, medical products are classified into different categories. In the case of high risk products, which include breast implants, ${ }^{51}$ the producer is allowed to affix the CE (Conformité Européenne) mark that indicates conformity with the relevant safety standards, only if the product design has been certified by a 'notified body'. Notified bodies are certification bodies that have been notified by Member States to the European Commission, thus the notion 'notified bodies'.

Notified bodies need to satisfy a number of requirements set out in Annex XI to the abovementioned Directive 93/42/EEC, relating to: the independence from the manufacturer of the notified body and its personnel; its professional integrity and financial independence; the fact that it has sufficient resources and facilities to carry out its tasks; the relevant qualifications of personnel; the

\footnotetext{
${ }^{48}$ See, eg, Harm Schepel, The Constitution of Private Governance. Product Standards in the regulation of Integrating Markets (Hart Publishing, 2005).

${ }^{49}$ Council Directive 93/42/EEC of 14 June 1993 concerning Medical Devices [1993] OJ L 169/1.

${ }^{50}$ Regulation (EU) 2017/745 of the European Parliament and of the Council of 5 April 2017 on Medical Devices, amending Directive 2001/83/EC, Regulation (EC) No 178/2002 and Regulation (EC) No 1223/2009 and repealing Council Directives 90/385/EEC and 93/42/EEC [2017] OJ L 117/1.

${ }^{51}$ See Commission Directive 2003/12/EC of 3 February 2003 on the reclassification of breast implants in the framework of Directive 93/42/EEC concerning medical devices [2003] OJ L $28 / 43$.
} 
impartiality of the organisation and, finally, its protection by professional indemnity insurance. In formal terms, notified bodies need to be designated by the competent authority of their home state or by another body that has been entrusted with the task of providing accreditation services. It is the special expertise of that notified body that adds the necessary safety to the process.

Duties of the notified body relate to the pre-marketing stage and to postmarketing monitoring. At the pre-marketing stage, the notified body must, on application of the producer, audit the quality management system of the producer. This system must guarantee that the products conform to the provisions of the Directive which apply to them at every stage of manufacture, from design to final inspection. The notified body must also examine the manufacturer's dossier relating to the product design in order to ensure its conformity with the requirements of the Directive. ${ }^{52}$

At the post-marketing stage, the Directive imposes surveillance duties on the notified body. According to section 5.1 of Annex II, the aim of surveillance is to ensure that the manufacturer duly fulfils the obligations imposed by the approved quality management system. To that end, the notified body must periodically carry out appropriate inspections and assessments to make sure that the manufacturer applies the approved quality management system, and must supply the manufacturer with an assessment report (section 5.3 of Annex II). In addition, the notified body may pay unannounced visits to the manufacturer. At the time of such visits, the notified body may, where necessary, carry out or ask for tests to be carried out in order to check that the quality management system is working properly (section 5.4 of Annex II).

In the PIP case, the French producer Poly Implant Prothèse (PIP) had produced cheap and defective breast implants that were used on about 300000 women worldwide. When the scandal was revealed by the French authorities, PIP filed for bankruptcy, and the attention of the victims turned to TÜV Rheinland which had certified the product design (correctly) but which had also been responsible, as a notified body, for monitoring on-going compliance with the product design. Victims of the PIP scandal allege that the fraudulent behaviour of PIP had been possible only because TÜV Rheinland had always announced its inspection visits eleven days in advance, with the result that PIP had been able, for the duration of the inspection, to change the manufacturing process back to the certified system. Moreover, victims claimed that TÜV Rheinland should have checked the books which would have revealed that the amount of medical silicone purchased by no means corresponded with the number of breast

\footnotetext{
${ }^{52}$ See, in particular, Annex II Sec 3.3 and 4.3 of Council Directive 93/42/EEC of 14 June 1993 concerning Medical Devices [1993] OJ L 169/1.
} 
implants produced. TÜV Rheinland defended itself by arguing that section 5.4 of Annex II did not require notified bodies to pay unannounced visits in the absence of any cause for mistrust, and that no such cause had been recognisable. ${ }^{53}$

Leaving aside the controversial question of whether or not TÜV Rheinland had actually breached its duties under the Medical Devices Directive, a question that required clarification from the European Court of Justice (ECJ) arose in the case of Elisabeth Schmitt. ${ }^{54}$ The case was a referral from the German BGH, ${ }^{55}$ and was ultimately decided by the BGH in the negative ${ }^{56}$ but is still pending in French courts. ${ }^{57}$ The relevant question for this article is whether or not TÜV Rheinland would be liable to the victims if it did breach its duties (of care).

53 For detailed discussion, see Peter Rott and Carola Glinski, 'Die Haftung der Zertifizierungsstelle im Produktsicherheitsrecht' [2015] (1) Zeitschrift für Europäisches Privatrecht(ZEuP) 192; Barend van Leeuwen, 'PIP Breast Implants, the EU's New Approach for Goods and Market Surveillance by Notified Bodies' (2014) 5 European Journal of Risk Regulation 338; Jan De Bruyne and Cedric Vanleenhove, 'Liability in the Medical Sector: The 'Breast-Taking' Consequences of the Poly Implant Prothèse Case' (2016) 24 European Review of Private Law 823.

54 Elisabeth Schmitt v TÜV Rheinland LGA Products GmbH (C-219/15) [2017] ECJ, 128; on which see Peter Rott, 'Pflichten und Haftung der "benannten Stelle" bei HochrisikoMedizinprodukten' [2017] NJW 1146; Gert Brüggemeier, 'Fehlerhafte Brustimplantate und die Haftung der Zertifizierungsinstitute - Das EuGH-Urteil in der Rechtssache Schmitt v TÜV Rheinland' [2017] Medizinrecht (MedR) 527; Unger, above n 9; Jörg Heynemann, 'Haftung der Benannten Stelle für die fehlerhafte "Überwachung" mangelhafter Medizinprodukte oder allgemeines Lebensrisiko?', (2017) Gesundheit und Pflege (GuP) 98; Marc Oeben, 'Drittschutzwirkung der Konformitätsbewertung und Pflichtenkorsett der Benannten Stelle' [2017] Medizinprodukterecht (MPR) 42; Julia Kathrin Degen, 'Die Haftung der "Benannten Stelle” iSv § 3 Nr 20 MPG' [2017] VersR 462; Gerhard Wagner, 'Marktaufsichtshaftung produktsicherheitsrechtlicher Zertifizierungsstellen’ [2018] Juristenzeitung (JZ) 130.

${ }^{55}$ Bundesgerichtshof [German Federal Court of Justice], VII ZR 36/14, 9 April 2015, reported in [2015] VuR 271 with case note by Peter Rott.

${ }^{56}$ Bundesgerichtshof [German Federal Court of Justice], VII ZR 36/14, 22 June 2017, [2017] VuR 392, with case note by Peter Rott. That, however, may not have been the final word yet as the claimant has raised a number of potential (new) reasons why TÜV Rheinland should have mistrusted PIP and its products, reasons that the BGH could not, for reasons of civil procedural law, consider in its decision on the case of Ms Schmitt. In contrast, these reasons will have to be considered in other cases that are still pending in the instance courts. See also Heynemann, above n 54, 100; Markus Finn, 'Keine Haftung mangels nachgewiesener Hinweise auf minderwertige Brustimplantate' [2017] NJW 2590, 2592. For critique, see also Gert Brüggemeier, 'Luxemburg locuta, causa finita? - Eine Nachbetrachtung der juristischen Behandlung der sogenannten PIP-Affäre in Deutschland' [2018] JZ 191.

57 The Tribunal de commerce de Toulon [Toulon Commercial Court], 2011F00517, 14 November 2013 (Société GF Electromedics \& société EMI importacao e Distribucao Ltda \& société J\& D Medicals et autres intervenants volontaires), found TÜV Rheinland liable; on which see Véronique Fröding, 'Industriesilikon in Brustimplantaten - Urteil des Handelsgerichtes 
a) EU Law The Medical Devices Directive had established a public law control system involving producers and notified bodies but was silent on civil law remedies. Since the ECJ had nevertheless found individual remedies in EU law in the past ${ }^{58}$ academics anticipated that it would come to the same result if it found that the Medical Devices Directive, and the role of notified bodies therein, was to protect patients.

To determine whether they were right about this an analysis of the function of the notified bodies within the system of medical devices safety law is required. This function has been subject to controversy, in particular in the German courts dealing with the PIP scandal. The debate has been triggered by the abovementioned requirement of $\S 823$ paragraph 2 BGB that the law that was breached (Schutzgesetz) must be meant to protect the victim.

The notified body is involved in the certification of a particular medical device by virtue of a contract with the producer. ${ }^{59}$ On this basis some German courts had concluded that the role that medical devices law ascribes to notified bodies is merely to help the producer to achieve the level of safety that is required to put its products on the market. Consequently, they argued that it was not for the notified body but only for the producer to protect the victims from unsafe products. ${ }^{60}$ They found support for their view in the fact that public authorities are also involved in the safety of medical devices as the control of products that have been put into circulation lies in their hands; from which they concluded

\footnotetext{
(Tribunal de Commerce) Toulon vom 14 November 2013' [2014] MPR 1. On appeal, the Cour d'appel d'Aix-en-Provence [Aix-en-Provence Court of Appeal], No 2015/21, 22 January 2015, found no breach; on which see Véronique Fröding, 'PIP Brustimplantate: Warum das Berufungsgericht Aix-en-Provence die Haftung des TÜV abgelehnt hat' (2015) MPR 162. The Cour de cassation has repealed that decision and ordered a new trial before the Cour d'appel de Paris [Paris Court of Appeal], Arrêt n ${ }^{\circ}$ 610, 10 October 2018 (15-26.093); Arrêt n ${ }^{\circ}$ 615, 10 October 2018 (16-19.430).and Arrêt $n^{\circ}$ 616, 10 October 2018 (17-14.401), all available at $<$ https://www.courdecassation.fr>.

${ }^{58}$ See, eg, the cartel law case of Courage Ltd v Bernhard Crehan (C-453/99) [2001] ECJ 465, para 27.

${ }^{59}$ See, eg, Bundesgerichtshof [German Federal Court of Justice], III ZR 339/09, 31 March 2011, reported in [2011] Monatsschrift des deutschen Rechts (MDR) 658.

${ }^{60}$ See especially Oberlandesgericht Zweibrücken [Zweibrücken Higher Regional Court], 4 U 66/13, 30 January 2014, reported in [2014] MPR 62, 65 with case note by Boris Handorn: 'Industriesilikon in Brustimplantaten - OLG Zweibrücken bestätigt fehlende Haftung der Benannten Stelle', [2014] MPR, 84. See also Andreas Spickhoff, in: Andreas Spickhoff (ed), Medizinrecht (C H Beck, 2nd ed, 2014) § 15a MPG para 3; Hannes Beyerbach, 'Haftung der Benannten Stelle für Mängel in der Medizinprodukteherstellung?' [2015] Gesundheitsrecht (GesR) 522, 525.
} 
that there should be no duplication of responsibilities in the post-marketing control of medical devices. ${ }^{61}$

In contrast, some academic authors argued that the role of notified bodies in the law on high-risk medical devices was precisely to protect patients. ${ }^{62}$ They found support in the recitals of the Directive as well as in a statement by the Commission, according to which '[c]onformity assessment is a key to trust and confidence in the regulatory system's capacity to protect patients and citizens'. ${ }^{63}$ Advocate General Sharpston shared the view

that it is the purpose and intention of Directive 93/42 that, in the case of Class III medical devices, the notified body responsible for auditing the quality system, examining the design of the product and surveillance acts in order to protect all potential patients and may therefore, in the event of a culpable infringement of an obligation under that directive, be liable to the patients and users concerned. ${ }^{64}$

The Court confirmed that the Directive serves, amongst other things, the health and safety of patients.

Nevertheless, the ECJ held that the Directive did not require Member States to impose civil liability on notified bodies who breach their duties under the Directive, while at the same time not excluding the possibility of national law imposing such liability. ${ }^{65}$ The judgment was criticised in academic writing for two reasons. Brüggemeier compares the safety system of medical devices law with the German national safety systems and concludes that, functionally, the certification bodies fulfil a public task and, therefore, their failure should trigger state liability. ${ }^{66}$ Other authors point out that the need for the Medical Devices

\footnotetext{
${ }^{61}$ See expressly Oberlandesgericht Zweibrücken [Zweibrücken Higher Regional Court], 4 U 66/13, 30 January 2014, reported in [2014] MPR 62, 65.

${ }^{62}$ For detailed analysis, see Rott and Glinski, above n 53, 204. See also Gerald Spindler, in Beate Gsell et al (eds), Beck-online Großkommentar (C H Beck, 2017) § 823 Schadensersatzpflicht, para 304; Oberlandesgericht Frankfurt [Frankfurt Higher Regional Court], 8 U 168/13, 13 January 2015, [2015] BeckRS 09145.

${ }^{63}$ European Commission Communication on medical devices, COM (2003) 386 final, 6.1.

${ }^{64}$ Elisabeth Schmitt v TÜV Rheinland LGA Products GmbH (C-219/15) [2016] ECJ 694, para 40 (AG Sharpston).

${ }^{65}$ Elisabeth Schmitt v TÜV Rheinland LGA Products GmbH (C-219/15) [2016] ECJ, paras 5560.

${ }^{66}$ See Brüggemeier, above n 54, 528.
} 
Directive to be effective would seem to make a liability regime indispensable. The PIP scandal was seen to provide ample evidence of this. ${ }^{67}$

b) German Law - Breach of a Statutory Duty As mentioned above, the BGH had raised the question of the protective aim of the notified bodies' role and function because of the specific tort law provision of $\S 823$ paragraph 2 BGB, which imposes liability for the breach of a statutory duty only if that duty is to protect the victim. That question was answered by the ECJ in the affirmative so that, under German tort law, the potential liability of notified bodies for damage to third parties is confirmed. ${ }^{68}$

The certification body and the producer would then be jointly and severally liable ( $\S 830$ paragraph $1 \mathrm{BGB}$ ). Unless the producer is bankrupt, the certification body could then claim redress from the producer who has the primary responsibility for the defective products ( $\S 840$ BGB).

Other potential grounds of liability have been left open or have not been discussed at all by the courts, whereas they have been raised in academic writing.

c) German Law - General Tort Law Liability could also stem from the general tort law provision of $\S 823$ paragraph 1 BGB. In particular, Brüggemeier has convincingly argued that, through its very function in the safety control system of medical devices law, the notified body owes a duty of care to the recipients of breast implants not to harm them through negligent monitoring of the producer. ${ }^{69}$ In that sense, the duty of care corresponds with the protective purpose of the law, the breach of which triggers liability under $\S 823$ paragraph 2 BGB. $^{70}$ In fact, $\S 823$ paragraph 1 BGB is the more appropriate route, as $\S 823$ paragraph 2 is meant to apply where $\S 823$ paragraph 1 is inapplicable because none of the interests that are protected by $\S 823$ paragraph 1 (life, health and so on) is concerned, thus mainly in cases of pure economic loss.

As opposed to liability under $\S 823$ paragraph $2 \mathrm{BGB}$, liability under $\S 823$ paragraph $1 \mathrm{BGB}$ is not delimited to the breach of the public law duties laid

\footnotetext{
${ }^{67}$ See Rott, above n 54, 1147; Wagner, above n 54, 136. See also Maria Mesch, 'BGH: Haftung der benannten Stelle bei fehlerhaften Medizinprodukten' [2017] Kommentierte BGHRechtsprechung Lindenmeier-Möhring (LMK) 395640.

${ }^{68}$ See Bundesgerichtshof [German Federal Court of Justice], VII ZR 36/14, 22 June 2017, [2017] VuR 392.

${ }^{69}$ See Brüggemeier, above n 54, 529. See also Wagner, above n 54, 136.

${ }^{70}$ Wagner, above n 54, 136.
} 
down in the protective law but depends on the general tort law criteria of foreseeability and avoidability of damage. Public law rules only provide for minimum requirements on what needs to be done to prevent damage. The same applies to other types of public or private standards or to 'best practices' which provide mere indicators on what may be sufficient under normal circumstances. ${ }^{71}$ Thus, the notified body would not be protected by the standard of care of the public law regime of the Medical Devices Directive if it was foreseeable that this was insufficient to prevent harm to victims. ${ }^{72}$ In particular, the regime of $\S 823$ paragraph 1 BGB could overcome the lack of an explicit duty to pay unannounced visits to the producer's factory, as unsolicited visits can be regarded as a common standard in the certification business. ${ }^{73}$ In its decision on the PIP case, the BGH has not even mentioned this possible route.

d) German Law - Contract with Protective Effect on Third Parties Finally, liability could arise out of a contract between the producer and the notified body, with protective effects on the recipients of the breast implants.

In the PIP case, the German OLG [Oberlandesgericht, Higher Regional Court] Zweibrücken had explicitly rejected the idea of the contract between PIP and TÜV Rheinland having protective effect for the recipients of breast implants. This conclusion was, however, based on the above-mentioned misapprehension that the involvement of the notified body was merely meant to help the producer. The BGH has not provided further clarification because it did not see a breach of duty in the first place.

Given the 'real purpose' of the notified body to protect patients, as confirmed by the ECJ, the contract between PIP and TÜV Rheinland could be classified as a contract with protective effects on the recipients of breast implants. ${ }^{74}$

\footnotetext{
${ }^{71}$ See generally Bundesgerichtshof [German Federal Court of Justice], VI ZR 11/52, 3 December 1952, reported in [1953] VersR 82 (forest fire); Bundesgerichtshof [German Federal Court of Justice], VI ZR 223/82, 18 September 1984, reported in [1985] NJW 47 (industry emissions); Bundesgerichtshof [German Federal Court of Justice], VI ZR 183/97, 26 May 1998, reported in [1998] NJW 2436 (fireworks). For detailed analysis, see Carola Glinski, Die rechtliche Bedeutung der privaten Regulierung globaler Produktionsstandards (Nomos, 2010) 263-79, with further references.

72 See Rott and Glinski, above n 53, 207; Brüggemeier, above n 54, 530.

${ }^{73}$ For references, see Rott and Glinski, above n 53, 206.

${ }^{74}$ See also Brüggemeier, above n 56, 195; cf Wagner, above n 54, 137, who points at the fact that the duties of the notified body are not defined in the contract but by law. Still, the notified body only became involved because of a contract with the producer, whereas the producer could have just as well chosen another notified body.
} 
e) Liability under English Tort Law Lawsuits against TÜV Rheinland have not been brought in the UK. Victims from the UK have joined collective actions in France, or claimants have resorted to suing the traders that have supplied breast implants, or their insurers ${ }^{75}$ or their clinics or surgeons, or credit card companies under s 75 of the Consumer Credit Act 1974 which gives a 'like claim' against finance providers where claimants purchased their operations using their credit cards. ${ }^{76}$

The PIP situation seems to be comparable to the above-mentioned case of Perrett $v$ Collins,${ }^{77}$ where the Court of Appeal based the safety officer's duty of care on his function within a system of controls that is meant to protect the passengers and the public from crashes of unsafe aircraft. Likewise, notified bodies are under statutory obligations to monitor producers of medical devices, and likewise, this is a function that, according to the ECJ in Elisabeth Schmitt, notified bodies exercise in an equivalent way in the area of medical devices. ${ }^{78}$

\section{B Voluntary Systems with Mandatory Certification}

Beyond the establishment of mandatory CSR certification schemes, there have been calls for a long time to make compliance, with human rights norms in particular, but also with social and environmental protection, attractive for transnational corporations. In various ways, systems have been set up which producers or traders can voluntarily join, but which, if joined, require mandatory certification of compliance with certain rules. In the following, we briefly consider two types of such systems.

\section{$1 \quad$ Public Law-Induced Voluntary Systems with Mandatory Certification}

Public law-induced certification systems already exist in the transnational sphere in the area of biofuels. ${ }^{79}$ The promotion of biofuels is part of the effort of EU law, under Directive 2009/28/EC on the promotion of the use of energy

\footnotetext{
${ }^{75}$ Most claims have been settled in the meantime. For an account of the complicated litigation, see Travelers Insurance Company Ltd v XYZ [2018] EWCA Civ 1099.

${ }^{76}$ See also Barend van Leeuwen, European Standardisation of Services and its Impact on Private Law (Hart Publishing, 2017) 150.

77 [1998] EWCA Civ 884.

${ }^{78}$ See above, IV A 2 a.

${ }^{79}$ For detailed analysis, see Carola Glinski, 'Certification of the Sustainability of Biofuels' in Rott, above $n 3$ (forthcoming).
} 
from renewable sources, ${ }^{80}$ to achieve renewable energy promotion goals. Thus, under article 3(4) of Directive 2009/28/EC, each Member State shall ensure that the share of energy from renewable sources in all forms of transport in 2020 is at least 10 per cent of the final energy consumption in transport in that Member State. In relation to energy from biofuels and bioliquids, article 17 of the Directive lays down sustainability criteria that need to be met irrespective of whether the raw materials were cultivated inside or outside the territory of the EU. Amongst other things, the greenhouse gas emission saving from the use of biofuels must reach certain thresholds, and biofuels shall not be made from raw material obtained from land with high biodiversity value or from land with high carbon stock.

As direct public law control of compliance with these requirements in many biofuels producing countries outside the EU is difficult, the EU and the Member States have recognised private certification schemes. The schemes have to meet the minimum standards of EU law, though they can add further substantive standards, and the schemes (as well as the certification bodies in some Member States) need the approval of the European Commission or, in the case of national schemes, of the competent authorities of the Member States.

Leaving aside the controversy about the success of the system, ${ }^{81}$ it should be clear that such a system is, in principle, similar in its design to the medical devices safety system of EU law, although its purpose is of course limited to climate protection. Nevertheless, if such a system were designed, for example, to protect workers in supply chains, the logic of the PIP case could be transferred to the liability of the certification organisations involved.

As far as the liability of certification bodies is concerned, the difference from the situations discussed previously is that the meeting of certain requirements by the parent company or buyer in a supply chain, including the involvement of a certification body, is entirely voluntary. Thus, the breach of the duties under such schemes cannot be seen as the breach of a statutory duty, whereas it may well be the breach of a duty of care that is derived from the participation in the scheme, or as the breach of a contract with protective effects on third parties.

\footnotetext{
${ }^{80}$ Directive 2009/28/EC of the European Parliament and of the Council of 23 April 2009 on the Promotion of the Use of Energy from Renewable Sources and Amending and Subsequently Repealing Directives 2001/77/EC and 2003/30/EC [2009] OJ L 140/16.

${ }^{81}$ For a critical analysis of the voluntary schemes at EU level, see the European Court of Auditors, Special Report No18/2016: The EU system for the Certification of Sustainable Biofuels (Publications Office of the European Union, 2016) 27.
} 
a) German Law - Contract with Protective Effects on Third Parties In the abovementioned scenario, the certification body is involved through a contract with the producer or service provider who seeks to reap the benefits of socially responsible behaviour and therefore needs to meet specified CSR requirements.

What is crucial for a protective effect on third parties (the workers) is that, in an objective interpretation of the contract, the 'real beneficiaries' of the contract must be the employees of subsidiaries or suppliers. The fact that the 'real beneficiaries' are the employees of subsidiaries or suppliers can be derived from the purpose of the certification exercise. If certification of the safety of those employees is a precondition for tax advantages or subsidies, the purpose of protecting the employees is apparent, as the state thereby intends to live up, for example, to its own protective duties stemming from international law instruments, ${ }^{82}$ or simply to self-defined protective aims.

In this regard, the situation - a contractual agreement with protective effects on third parties - does not differ from the situation under a mandatory certification scheme.

b) German Law - Tort Law Under $\S 823$ paragraph 1 BGB, the question is whether the certification organisation has the duty (Verkehrspflicht) to contribute to the prevention of damage by exercising skill and care in detecting safety problems and notifying its contracting partner - the parent company or the buyer in a supply chain - of them. Clearly, there is no legal obligation to do so in the absence of a legal regime that requires certification, and the certification organisation would not have an original duty of care either, as it has neither created the risk nor is it originally responsible for the safety of the factory. However, its duty to prevent damage can be derived from the duty of care on the part of its contracting partner.

\footnotetext{
${ }^{82}$ Such as the so-called Ruggie Framework. See John Ruggie, Special Representative, Protect, Respect and Remedy: A Framework for Business and Human Rights, UN doc A/HRC/8/5 (7 April 2008) <http://www.reports-and-materials.org/Ruggie-report-7-Apr-2008.pdf $>$; John Ruggie, Special Representative, Guiding Principles on Business and Human Rights: Implementing the United Nations "Protect, Respect and Remedy" Framework, UN doc A/HRC/17/31 (31 March 2011) <http://www.ohchr.org/documents/issues/business/A.HRC. 17.31.pdf $>$. On the state responsibility to promote human rights extraterritorially, see Markus Krajewski, 'Regulierung transnationaler Wirtschaftsbeziehungen zum Schutz der Menschenrechte: Staatliche Schutzpflichten jenseits der Grenze?' in Markus Krajewski (ed), Staatliche Schutzpflichten und unternehmerische Verantwortung für Menschenrechte in globalen Lieferketten (FAU University Press, 2018) 103.
} 
Obviously, a person can take over duties from another person (or company) and thereby assume the duty of care. For example, if an independent contractor or a tenant undertakes, by way of contract, to sweep snow for a house owner, he will be liable if, due to his negligence, someone slips and suffers damage. ${ }^{83}$

The concept requires two elements, however: an existing duty of care ${ }^{84}$ on the part of the parent company or the buyer in a supply chain, and the taking over of that duty of care by the certification organisation.

The first requirement is easily satisfied where it is the producer and employer who commissions a certification body to monitor certain aspects of health and safety or of environmental protection. Usually, however, it will be the parent company or the buyer in a supply chain who does so. The parent company, or the buyer, in a supply chain, are however not under a legal duty to participate in a scheme but may only do so because the scheme offers them advantages, such as tax reduction.

They may, however, be under a legal duty for other reasons, in particular because they are in control of the production site. This situation is, however, unrelated to state benefits and will be discussed later.

c) English Law Under the general rules of the tort of negligence, the crucial question would be whether, by entering into a certification contract, the certification organisation assumes a duty of care for the workers. The answer to this must be found in an application of the three step test of Caparo $v$ Dickman, with special consideration of the case law relating to the assumption of responsibility. Foreseeability is not at issue as it is perfectly foreseeable that negligent certification will lead to inactivity on the part of the parent company or buyer in a supply chain, whereas the parent company or buyer could otherwise take action to make the immediate producer remedy the problem. Thus, we focus on proximity and on whether it is fair, just and reasonable to impose liability on the certification body.

Most notably, in Chandler $v$ Cape, the concept of assumption of responsibility was extended by the Court of Appeal to cover a situation where a parent company had 'relevant' (not total) control over its subsidiary; the parent had,

\footnotetext{
${ }^{83}$ See, eg, Bundesgerichtshof [German Federal Court of Justice], VI ZR 126/07, 22 January 2008, reported in [2008] NJW 1440. See also Bundesgerichtshof [German Federal Court of Justice], VI ZR 186/88, 17 January1989, reported in [1989] NJW-Rechtsprechungsreport (NJW-RR), 394 (cleaning of pathways in a housing area).

${ }^{84}$ See Gerhard Wagner in Säcker et al, Münchener Kommentar zum Bürgerlichen Gesetzbuch, (C H Beck, $7^{\text {th }}$ ed, 2017) vol $6 \S 823$ BGB paras 464-7.
} 
or ought to have had, superior knowledge on some relevant aspect of health and safety in the particular industry; the subsidiary's system of work was unsafe and the parent company knew this or ought to have known this; and the parent company knew or ought to have foreseen that the subsidiary or its employees would rely on the parent company using its superior knowledge for the employees' protection. ${ }^{85}$

The situation of a certification body that has been entrusted, for the sake of state benefits, with safety certification to the benefit of workers, has elements of both expert liability, as in Hedley Byrne and subsequent case law, and the Chandler $v$ Cape situation. Certification bodies are entrusted with their work because they are experts in the relevant areas, including health and safety. Their task is to find out whether the subsidiary's or supplier's system of work is unsafe, and prevention of damage depends on their discovering unsafe elements and notifying their contracting partner of them. Although there has been no legal precedent to this effect, the situation appears to be well capable of attracting negligence liability due to the assumption of responsibility. This would surely seem to be 'fair, just and reasonable', if it is the state that calls for expert certification as a precondition to the receipt of state benefits, with the aim of protecting workers within the supply chain, or the neighbours of hazardous production sites.

In contrast, no liability would arise where a social auditor is not entrusted with a particular task, as in the Canadian case of Das v George Weston ${ }^{86}$ Victims of the Rana Plaza collapse had sued not only Loblaws, a Canadian company that had sourced garments from a factory in Rana Plaza, but also the certification organisation Bureau Veritas that had performed a 'social audit' for Loblaws in Rana Plaza. That 'social audit' did not include the assessment of the structural integrity of Rana Plaza, which would have been part of additional services for additional costs. ${ }^{87}$ This limitation was held to also limit Bureau Veritas' duty of care.$^{88}$ In fact, in oral hearings in the Ontario Superior Court of Justice in this case, the defendant Bureau Veritas acknowledged that if it had negligently performed some service within the ambit of its social audit and an employee of the company it audited had been injured as a result, then Bureau Veritas would be exposed to liability. ${ }^{89}$

\footnotetext{
${ }^{85}$ Chandler v Cape plc [2012] EWCA Civ 525 [80].

${ }^{86}$ Das v George Weston Limited 2017 ONSC 4129.

${ }^{87}$ Ibid [53].

${ }^{88}$ Ibid [446].

${ }^{89}$ Ibid [444].
} 


\section{Private CSR Systems with Mandatory Certification}

Likewise, parent companies or traders may sign up to an existing private CSR standard that provides for mandatory certification, such as, for example, the Forest Stewardship Council standards or the SA8000 standard of Social Accountability International. ${ }^{90}$ The involvement of the certification organisation then becomes by itself a contractual duty owed by the parent company to the standardisation organisation.

At the international level, private CSR systems are often substitutes for missing international legal instruments, and the standards that some of them have developed have been considered to be international standards, for example for the purposes of WTO law. ${ }^{91}$ Their setup sometimes comes close to national or EU scenarios in that the certification organisation is accredited by a private standard-setting organisation, needs to satisfy specific eligibility requirements and has to follow specific rules of operation as set up by the standard-setting organisation. One example would be the SA8000 system, under which certified organisations must provide a safe and healthy workplace environment ${ }^{92}$ and under which RINA had certified the Ali Enterprises factory in Karachi, Pakistan. ${ }^{93}$

In the SA8000 system, all SA8000 audits are carried out by certification bodies that receive accreditation from Social Accountability International's (SAI's) independently managed affiliate, Social Accountability Accreditation Services (SAAS). The accreditation function encompasses oversight of auditors and the management systems of the auditing companies. SAI provides guidance on the Standard's implementation and determines the program's auditing methodology. SAAS assesses a certification body's competence through a series of audits which review the management, processes, and auditor qualifications of the certification body's certification process. ${ }^{94}$

The certification body then evaluates the implementation of the accredited social system at a factory, farm or other organisation to ensure compliance with all elements of the system. This includes conducting mandatory unannounced

\footnotetext{
${ }^{90}$ Social Accountability International, Social Accountability 8000 International Standard (June 2014) 9 <www.sa-intl.org/_data/n_0001/resources/live/SA8000\%20Standard\%202014.pdf>.

${ }^{91}$ See Carola Glinski, 'CSR and the Law of the WTO - The Impact of Tuna Dolphin II and ECSeal Products' [2017] (1) Nordic Journal of Commercial Law 120, 143.

${ }^{92}$ See Social Accountability International, above n 90, especially part 3.1.

${ }^{93}$ Bureau Veritas and TÜV Rheinland have also been accredited by SA 8000 . See the list of accredited certification bodies at $<\mathrm{http}: / /$ www.saasaccreditation.org/?q=node/65 $>$.

${ }^{94}$ For details, various documents are available. See Social Accountability Accreditation Services, Document Library $<$ http://www.saasaccreditation.org/document-library $>$.
} 
audits. Interestingly, the number of unannounced audits varies, depending on the risk assessment for each country. ${ }^{95}$ Pakistan and Bangladesh are in the 'highest risk' category and must be audited most frequently. ${ }^{96}$

This is different from the situation discussed above in that that the state is not involved at all.

\section{German Law}

a) Contract with Protective Effect on Third Parties

As described

in the previous section, the involvement of a certification organisation is voluntary, and the duties of the certification organisations are not defined by law or even endorsed by the state but have been set up by private standardisation organisations. Nevertheless, the institutional accreditation and control of the certification bodies and the composition of the private standardisation organisation as a multi-stakeholder organisation aims at the promotion of CSR including, in particular, responsibility to the workers in transnational production or supply chains. This makes it clear that the 'real beneficiaries' of the private systems are those workers (and other vulnerable groups).

In the past, agreements between industry and trade unions or NGOs have often been seen as programmatic rather than as having legal effects. ${ }^{97}$ This has changed, not least due to the disasters at Ali Enterprises and Rana Plaza. Private systems that have been established as a reaction to such disasters, such as the Bangladesh Accord, ${ }^{98}$ or that have been revised to give them teeth, are voluntary only concerning participation but impose legally binding requirements on their participants.

What remains is the question of whether, in such a situation, the parent company or trader and the certification organisation could agree to exclude the certification organisation's liability towards third parties. At least in standard terms, such an agreement would not hold. Under $\S 309$ no 8 a) BGB, a term

\footnotetext{
${ }^{95}$ Social Accountability Accreditation Services, Unannounced SA8000 Audits $<\mathrm{http}: / / \mathrm{www}$. saasaccreditation.org/UnannouncedSA8000Audits>.

${ }^{96}$ Social Accountability Accreditation Services, WGI Ranking for SA8000 System $<\mathrm{http}: / / \mathrm{www}$. saasaccreditation.org/sites/default/files/u4/full_country_list_for_SA8000_risk_assessment_po sted_to_web_2015.pdf>.

97 See, eg, Sebastian Krebber, 'Globalisierungsbedingter Verlust der Bindungswirkung staatlicher Regulierungen und die sich entwickelnden Alternativen' [2008] (2) Europäische Zeitschrift für Arbeitsrecht 315.

98 Accord on Fire and Building Safety in Bangladesh (13 May 2013) <http://bangladesh accord.org/wp-content/uploads/the_accord.pdf $>$.
} 
excluding liability for death or injury or limiting liability for death or injury to intentional and grossly negligent conduct is invalid. Moreover, it seems reasonable to argue that an exclusion clause would be contradictory to the very purpose of the contract and therefore be void (in relation to third parties that suffer harm). Instead, the parent company or trader and the certification organisation could agree on how they apportion liability between them, without effect on the claims of third parties.

b) German Tort Law Liability under $\S 823$ paragraph 1 BGB would depend on the same circumstances as discussed above (IV.B.1.b), namely, the existence of a duty of care on the part of the parent company or buyer in a supply chain, and the (partial) delegation of that duty to the certification body.

\section{English Law}

With regard to English tort law, the question is again one of a duty of care of the certification body. In contrast to the previously discussed situations, there is no legal, or state-induced, background to the tasks of certification bodies within a privately organised system.

English case law, however, suggests that legal duties can arise in such a context, as the case of Watson v British Boxing Board of Control ${ }^{99}$ shows. Michael Watson was a boxer who, on 21 September 1991, fought Chris Eubank under the supervision of the British Boxing Board of Control (BBBC), the British professional boxing governing body. The BBBC was a not-for-profit, private organisation, one of whose main concerns it was to promote safety standards in boxing. It had a series of rules on the medical coverage needed for boxing matches, which required two doctors to be present at all times. During the match, Watson was knocked out, and it was 7 minutes before doctors attended him. Eventually three doctors and an ambulance were needed. He was given no oxygen, and he was first sent to a hospital that lacked a neurosurgery unit. Watson spent 40 days in a coma and six years in a wheelchair. After recovering consciousness, he sued the BBBC, arguing that, because they laid down the rules governing professional boxing that were intended to ensure his safety, they owed him a duty of care and should have ensured that he was properly and immediately treated.

Upholding the judgment of the High Court, the Court of Appeal held that there was sufficient proximity between the claimant and the BBBC to give rise to a duty of care. The BBBC was a body with specialist knowledge and gave advice to a defined class of persons in the knowledge that that class would

${ }^{99}$ [2000] EWCA Civ 2116. 
rely upon that advice in boxing contests. The claimant in fact relied on the board to exercise skill and care in its efforts to protect his safety during the fight. Furthermore, the claimant belonged to a class of persons within the contemplation of the defendant, and the defendant was involved in an activity over which it had complete control and which would be liable to result in injury if reasonable care were not exercised.

Although certification systems, such as SA8000, are of course different from the activities of a sports body such as the BBBC, there are also similarities. In both cases the purpose of the system is, among other things, the health and safety of a defined class of persons - in the case of the certification system the employees of the companies that are certified - and both systems have mandatory rules, aimed at achieving their goals. In the case of certification, whereas the standardisation organisation lays down the rules, the certification bodies such as RINA or TÜV Rheinland play a crucial role in implementing them, and the whole system relies on problems being discovered and notified by the certification bodies. Thus, these monitoring bodies are responsible for injury to employees in the factories that they monitor if they fail to monitor the factories with reasonable care. This situation bears strong similarity to the role of notified bodies in EU product safety law.

Overall, the step from previous case law to the imposition of liability on certification bodies within a mandatory certification scheme would not seem to be too great. Further, imposing liability on them would seem to be 'fair, just and reasonable' in terms of the three step test of Caparo v Dickman.

\section{Entirely Voluntary Use of a Certification Body}

Parent companies or traders may decide entirely voluntarily to engage a certification organisation for support in the control of their subsidiaries or suppliers, for example, in order to impress customers with their CSR engagement. To that end, they may draw up their own set of requirements, compliance with which may then be controlled by the certification organisation. This was, for example, one of the business models of Bureau Veritas, as discussed in the above-mentioned case of Das $v$ George Weston. ${ }^{100}$

The decision to use certification voluntarily may, however, be based on a due diligence obligation on the parent company or trader, the fulfilment of which may be assisted by a certification body.

${ }^{100}$ Das v George Weston Limited 2017 ONSC 4129 [444]. 
As a prominent example, France has now introduced a statutory due diligence obligation with Loi $n^{\circ} 2017-399 d u 27$ mars 2017 relative au devoir de vigilance des sociétés mères et des entreprises donneuses d'ordre [Law no 2017-399 of 27 March 2017 relating to the Duty of Vigilance of Parent Companies and of Ordering Companies]. The draft law provided for both public law enforcement and the civil liability of parent companies that breach their due diligence obligations. However, the public law enforcement through fines has been declared unconstitutional by the Conseil consitutionnel [French Constitutional Court], due to the uncertainty of the meaning of terms such as 'human rights', 'fundamental freedoms' or 'reasonable care'. ${ }^{101}$ In contrast, civil liability has not been affected by that decision. The French law does not require certification of the corporation-wide system. Thus, the involvement of a certification organisation would be voluntary. Similar legislative projects or proposals have been put forward in Switzerland and Germany. ${ }^{102}$

The due diligence duty of the parent company or buyer can also be taken on contractually, for example through an agreement with an NGO or a trade union or through the company or buyer signing up to a system such as the Bangladesh Accord. Under this Accord the signatories commit themselves to 'the goal of a safe and sustainable Bangladeshi Ready-Made Garment (' $R M G$ ') industry in which no worker needs to fear fires, building collapses, or other accidents that could be prevented with reasonable health and safety measures'. ${ }^{103}$

Finally, the parent company or buyer may itself be under a duty of care under the tort of negligence because it has assumed responsibility for the wellbeing of workers, as the Court of Appeal held in the case of Chandler $v$ Cape. In the English case of Vedanta, the High Court and the Court of Appeal have indicated, in interim decisions concerning jurisdiction, that a parent company may be liable for damage arising from environmental pollution, in this case pollution resulting from the operation of a copper mine by a subsidiary. ${ }^{104}$

\footnotetext{
${ }^{101}$ Conseil constitutionnel [French Constitutional Court], decision n ${ }^{\circ}$ 2017-750 DC, 23 March $2017<$ https://www.conseil-constitutionnel.fr/decision/2017/2017750DC.htm>.

${ }^{102}$ In Switzerland, more than 80 NGOs, trade unions and shareholder unions have started an initiative; see Association Corporate Responsibility Initiative <http://konzern-initiative.ch>. For Germany, see Remo Klinger et al, Verankerung menschenrechtlicher Sorgfaltspflichten von Unternehmen im deutschen Recht (16 March 2016) <https://www.brot-fuer-diewelt.de/fileadmin/mediapool/2_Downloads/Fachinformationen/Sonstiges/gutachten_sorgfalts pflicht.pdf>.

${ }^{103}$ See the preamble to the Bangladesh Accord, above $\mathrm{n} 98$.

${ }^{104}$ See Lungowe v Vedanta Resources plc [2016] EWHC 975 (TCC) [115].
} 
In the aftermath of Chandler $v$ Cape, litigation against a buyer in a transnational supply chain was also started in Germany in the case of $\mathrm{KiK}$ (which is, however, to be assessed under the law of Pakistan), and the matter of corporate liability has also attracted broader attention in academic writing on German tort law. Initially, only a few academics argued in favour of corporation-wide organisation duties, including a duty of care for employees and neighbours of subsidiaries and even suppliers, ${ }^{105}$ whereas most authors were reluctant. ${ }^{106}$ However, an increasing number of academic lawyers tend to advocate for the recognition of liability in the right circumstances. ${ }^{107}$

The above issues are still unsettled, and this is not the place to enter into the debate. There is, however, a clear development towards parent companies bearing liability for the activities of their subsidiaries, and perhaps even of traders for their suppliers ${ }^{108}$ in the right circumstances. These circumstances include, in particular, a high level of control over the activities of subsidiaries or suppliers.

In all these situations - that is, in the situation of a statutory or a contractual due diligence duty as well as in the situation of a duty of care under the tort of negligence - parent companies or buyers may be compelled to put an organisational structure in place that allows them to monitor their subsidiaries or suppliers on a regular basis. As these entities may be spread around the globe, it would seem to make sense to outsource that task to specialist organisations that operate in the relevant region.

\footnotetext{
${ }^{105}$ For an early analysis, see Glinski, above n 71, 346. See also Miriam Saage-Maßß and Maren Leifker, 'Haftungsrisiken Deutscher Unternehmen und ihres Managements für Menschenrechtsverletzungen im Ausland' [2015] Betriebs-Berater (BB) 2499, 2502; Carola Glinski, 'UN-Leitprinzipien, Selbstregulierung der Wirtschaft und Deliktsrecht: Alternativen zu verpflichtenden Völkerrechtsnormen für Unternehmen?' in Krajewski, above n 82, 44, 6779.

${ }^{106}$ See Gehard Wagner, 'Haftung für Menschenrechtsverletzungen [2016] 80 Rabels Zeitschrift für ausländisches und internationales Privatrecht (RabelsZ) 717, 756-71; Marc-Philippe Weller, Luca Kaller and Alix Schulz, 'Haftung deutscher Unternehmen für Menschenrechtsverletzungen im Ausland' [2016] Archiv für civilistische Praxis (AcP) 216, $387,401-2$.

${ }^{107}$ See now Marc-Philippe Weller and Chris Thomale, 'Menschenrechtsklagen gegen deutsche Unternehmen' [2017] Zeitschrift für Unternehmens- und Gesellschaftsrecht (ZGR) 509, 520 3.

108 On which see Peter Rott and Vibe Ulfbeck, 'Supply Chain Liability of Multinational Corporations?' (2015) 23 European Review of Private Law (ERPL) 415; Terwindt et al, above n 1, 276-95.
} 


\section{German Law}

a) Contract with Protective Effect on Third Parties

In the case of safety certification, it is obvious that action by the company which commissions certification in the interests of workers in the factories of subsidiaries or suppliers (that is, the parent company or the buyer in a supply chain) depends on the certification organisation's detection and notification of unsafe conditions. Even if the fulfilment of a due diligence duty, or a duty of care towards employees or residents, does not require external certification, in other words even if it is left to the parent company or buyer to organise a system to implement the relevant standards, the involvement of a certification organisation will (objectively) serve the purpose of protecting the workers and/or residents as third parties to the certification contract. In other words, taking an objective approach, these workers and/or residents are the 'real beneficiaries' of the contract, as the certification contract is meant to ensure that certain safety conditions that the contracting company has imposed on or agreed with the subsidiary or supplier are met.

The question under the doctrine of 'contract with protective effect on third parties' is, however, whether the parent company or trader in question is responsible for those workers. Such responsibility would trigger the protective effect of the contract between the parent company or trader and the certification organisation. This is where the abovementioned due diligence duties - derived from statute, from a contract, or from signing up to a system like the Bangladesh Accord, or simply from the tort of negligence through assumption of responsibility - come into play.

Where no such duty of care exists on the part of the parent company or supplier, it seems difficult to argue that a duty of care arises on the part of the certification organisation.

b) Tort Law

As mentioned above, a certification body could have a duty of care towards workers at, or neighbours of, a production site if its contracting partner delegated such a duty to the certification body. This is possible only if the contracting partner, thus the parent company or buyer in a supply chain, is under a duty of care towards workers at, or neighbours of, the production site in the first place.

The delegation of the duty of care to an independent contractor (in this case the certification body) is normally based on a contract which, however, does not 
even need to be valid, according to the established case law of the BGH. ${ }^{109}$ The tort law logic giving rise to the duty of care of the delegate is that, through delegating the duty of care, the delegator legitimately comes to rely on the delegate and therefore lowers his or her own attention. ${ }^{110}$

The duty of care can also be partly delegated to an independent contractor. ${ }^{111}$ This would be the case here, as the contractual arrangement between the parent company or buyer and the certification body normally requires the certification body to monitor certain aspects of CSR and to notify the parent company or buyer of deficiencies, while it remains for the parent company or buyer to then take action.

A different question (and a side issue for the purposes of this article) is then whether or not the delegator also remains responsible for the damage, in particular in cases where the delegate breaches his or her duties negligently. According to established German case law, the delegator's duty of care changes into the duty to select and monitor the delegate carefully. The extent to which the delegator has to monitor the delegate depends on the expertise of the delegate. If the latter is an expert, the delegator only needs to exercise control if there is an indication of unreliability or other shortcomings on the part of the expert. ${ }^{12}$

As explained above, a duty of care of the certification organisation can be derived only from the duty of care of the parent company or of the buyer that commissions certification. If the parent company or buyer owes a duty of care, and if it organises its control system in such a way that a certification body takes over the task of visiting the production site and notifying the parent company or buyer of safety deficiencies, then the certification body partially takes over the duty of care and will be liable for damage resulting from negligence.

\footnotetext{
${ }^{109}$ See Bundesgerichtshof [German Federal Court of Justice], VI ZR 186/88, 17 January 1989, reported in [1989] NJW-RR 394, 395.

${ }^{110}$ See Wagner, above n 84, § 823 BGB para 467.

${ }^{111}$ See Bundesgerichtshof [German Federal Court of Justice], VI ZR 44/92, 3 November 1992, reported in [1993] NJW-RR 346, with further references. See also Guido Christensen, Verkehrspflichten in arbeitsteiligen Prozessen (Peter Lang, 1995) 90-7.

112 See, for example, Bundesgerichtshof [German Federal Court of Justice], VI ZR 166/05, 26 September 2006, reported in [2006] NJW 3628, 3629; Bundesgerichtshof [German Federal Court of Justice], VI ZR 369/12, 1 October 2013, reported in [2014] Neue Zeitschrift für Verkehrsrecht (NZV) 167, 169.
} 


\section{English Law}

The assessment under English law would again turn to Caparo v Dickman and the assumption of responsibility. Here, the situation appears to be somewhat different from that arising from a contract with protective effect on third parties, as the focus would seem to be more on the commitments of the certification organisation than on the interest of the parent company or buyer that commissions the certification.

Still, the level of control that the parent company or buyer exercises over the production, and thus the extent to which a detection of risks to health and safety by a certification body would be able and necessary to mitigate those risks through the influence that the parent company or buyer can have on the producer, would seem to play an important role in the overall assessment of proximity. Thus, where the parent company, or the buyer, has control over the production to an extent that it owes the workers, or even neighbours, a duty of care, it seems possible that, by taking over risk assessment or monitoring duties, a certification body assumes responsibility for the health and safety of the workers. Again, the argument is that the task of the certification body is a crucial element of the control system of the parent company or buyer, and any breach of its duties increases the risk to workers at and neighbours of the production site.

\section{E Causation and Standard of Proof}

Under all possible grounds of liability, the claimants would have to show causation, that is, they would have to show that the detection and notification of the safety problem to the contracting partner (the parent company or the buyer in the supply chain) would have led to the remediation of the problem and therefore would have prevented the damage.

The standard of proof differs between German law and English law. Whereas under English law the analysis is made on the balance of probabilities whether it is more likely than not that the damage would have been prevented had detection and notification occurred ${ }^{113}$ — proof under $\S 286$ of the German Code of Civil Procedure (ZPO) involves the court having to decide whether or not it regards a fact as true. The BGH has specified that the finding does not have to be beyond doubt, but a degree of certainty is required that silences any doubts even if they cannot be completely eliminated. ${ }^{114}$ In practice, this means

\footnotetext{
${ }^{113}$ See Miller v Minister of Pensions [1947] 2 All ER 372.

${ }^{114}$ See Bundesgerichtshof [German Federal Court of Justice], III ZR 139/67, 17 February 1970, reported in [1970] NJW 946. See also Bundesgerichtshof [German Federal Court of Justice],
} 
that German courts require probability that comes close to certainty. Thus, in the case of Elisabeth Schmitt, the first instance court had required the claimant to prove that the notified body, TÜV Rheinland, would have tested the silicone used at a particular time, and that at this time TÜV Rheinland would have detected that PIP was using industrial silicone. ${ }^{115}$ The appeal court reasoned similarly and required certainty that the industrial silicone would have been discovered during an unsolicited visit. ${ }^{116}$

\section{F Conclusion}

Certification bodies play a crucial role in assessing the risk of production and in discovering deficiencies, and even more so when it comes to production in developing countries of the Global South. They act, however, in a certain conflict of interest if they are paid by those that they are meant to control. Therefore, certification bodies need incentives to act in the best interest of those whose protection the certification exercise is meant to serve.

In a public law system, certification bodies that do not live up to their duties may, in principle, be sanctioned through fines or the withdrawal of accreditation; although the PIP saga demonstrates that public law systems do not always work well. In private law systems, which prevail in the regulation of transnational supply chain, such sanctions are by and large unavailable. In both situations, tort liability can complement or substitute public law sanctions and provide an incentive for certification bodies to comply with their legal or contractual duties.

This article has shown that under the right circumstances, certification bodies may owe a duty of care for the employees or even the neighbours of production sites. A duty of care owed by certification bodies has been confirmed in situations where the legal system expressly requires their involvement in safeguarding the health and safety of third parties, as recently illustrated in the PIP breast implant scandal. Such a duty of care should, however, also be assumed where certification bodies act within voluntary systems in which the state is involved, or in transnational private systems that are based on mandatory certification. Moreover, such bodies may come to owe a duty of care

VI ZR 221/92, 14 December 1993, reported in [1994] NJW-RR 567; Bundesgerichtshof [German Federal Court of Justice], IX ZR 311/95, 18 June 1998, reported in [1998] NJW 2969.

115 See Landgericht Frankenthal [Frankenthal Regional Court], 6 O 304/12, 14 March 2013, reported in [2013] Medizinprodukterecht (MPR) 134.

116 See Oberlandesgericht Zweibrücken [Zweibrücken Higher Regional Court], 4 U 66/13, 30 January 2014, reported in [2014] MPR 62, 65. 
by way of delegation from a parent company or buyer that itself is under a duty of care in relation to the health and safety of employees or neighbours of their subsidiaries or suppliers.

Different legal systems may use different legal concepts to achieve this result, but they would all seem to be sufficiently open to reflect the increased role of certification bodies in global supply chains. It seems only a matter of time until the right cases reach the courts. 